\title{
New perspectives for the future of the Maldives
}

\author{
Nils-Axel Mörner ${ }^{\mathrm{a}, *}$, Michael Tooley $^{\mathrm{b}}$, Göran Possnert ${ }^{\mathrm{c}}$ \\ ${ }^{a}$ Paleogeophysics and Geodynamics, Kraftriket 24, Stockholm University, Stockholm 10691, Sweden \\ ${ }^{\mathrm{b}}$ Geography and Archaelogy, University of Durham, Durham, UK \\ ${ }^{\mathrm{c}}$ The Angstrom Laboratory, Uppsala University, Uppsala, Sweden
}

Received 4 December 2001; accepted 7 May 2003

\begin{abstract}
Novel prospects for the Maldives do not include a condemnation to future flooding. The people of the Maldives have, in the past, survived a higher sea level of about $50-60 \mathrm{~cm}$. The present trend lack signs of a sea level rise. On the contrary, there is firm morphological evidence of a significant sea level fall in the last 30 years. This sea level fall is likely to be the effect of increased evaporation and an intensification of the NE-monsoon over the central Indian Ocean.
\end{abstract}

(C) 2003 Elsevier B.V. All rights reserved.

Keywords: Sea level changes; The Maldives; Indian Ocean; Prediction; No flooding; Evaporation

\section{Introduction}

The Maldives in the central Indian Ocean consist of some 1200 individual islands grouped in about 20 larger atolls. They rise as steep pinnacles from a depth of about $2500 \mathrm{~m}$ (Barbu, 1988) and consist of coral reefs, coral reef debris and coral sand. Their elevation is only of the order of 1-2 m. Hence, they have been condemned to be flooded in the near future (e.g. Hoffman et al., 1983; IPCC, 2001).

The first studies of the Maldives are nearly a century old (Gardiner, 1902; Agassiz, 1903; see also Davis et al., 1971; Prudy, 1981). More recently, Woodroffe (1992) presented the first sea level curve for the Maldives. He claimed that the islands were predominantly formed by catch-up coral reef growth.

\footnotetext{
* Corresponding author. Tel.: +46-8-164671; fax: +46-8164675.

E-mail address: morner@pog.su.se (N.-A. Mörner).
}

In contrast to this, Anderson (1998) recorded the last glaciation maximum (LGM) sea level at several places, indicating that much of the Maldives existed as land during this sea level low-stand.

In our present Maldives Project, we have been able to show that the atolls are not dominated by catch-up reef growth as previously believed, but are to a great extent of pre-Holocene age. We detected large karst areas, submarine caves and shore notches from islands existing prior to the last glaciation maximum. Rocks of Last Interglacial age were found to occur close to and below sea level and up to $+1.2-1.3 \mathrm{~m}$. Hence, the Maldives have remained more or less stable in Late Quaternary time. The Maldives lie right in the centre of the Earth's deepest geoid depression of about $-100 \mathrm{~m}$ (e.g. Mörner, 2000). At the last glaciation maximum (LGM), the geoid relief appears, however, to have been even greater.

A new sea level curve for the last 5000 years has been constructed (Fig. 1). It is a low-amplitude 


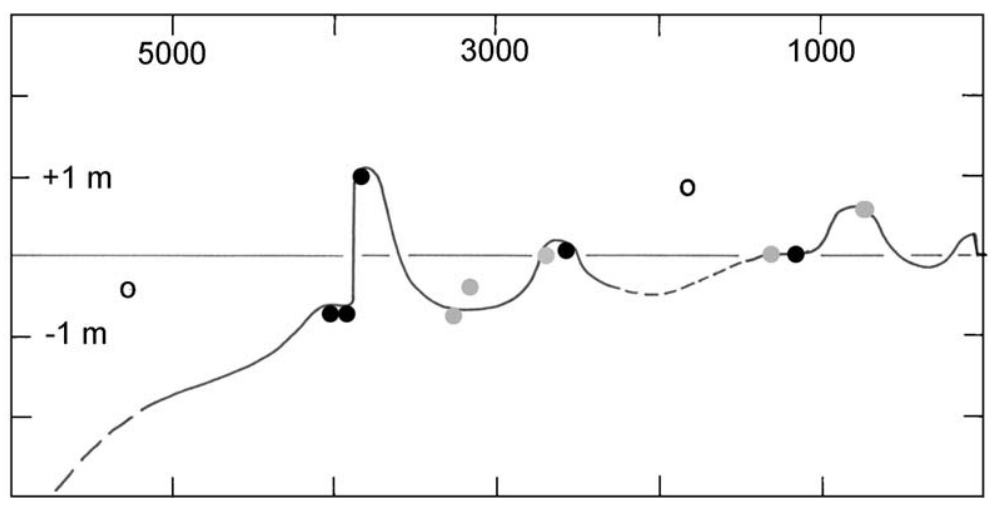

Fig. 1. Sea level curve for the last 5000 years for the Maldives. Black dots=past sea level positions dated by radiocarbon (AMS), grey dots = dates by Woodroffe (1992) with uncertain relation to sea level, open circles=dates by Woodroffe (1992) without closer relation to a former sea level. The sea level curve is oscillating with four levels above the present level; $+1.1-1.2 \mathrm{~m}$ at $3900 \mathrm{BP},+0.1-0.2 \mathrm{~m}$ at $2700 \mathrm{BP}$, $+0.5-0.6 \mathrm{~m}$ at $1000-800 \mathrm{BP}$ and $+0.2-0.3 \mathrm{~m}$ at $\mathrm{AD} 1900-1970$. The islands have been inhabited, at least, since $1500 \mathrm{BP}$.

oscillating curve, and includes stages when sea level was well above the present level: $+1.0-1.2 \mathrm{~m}$ at 3900 $\mathrm{BP},+0.1-0.2 \mathrm{~m}$ at $2700 \mathrm{BP},+0.4-0.5 \mathrm{~m}$ at $1000-$ $800 \mathrm{BP}$ and $+0.3 \mathrm{~m}$ at about $\mathrm{AD} 1900-1970$. As the islands were well inhabited by $1500-1300 \mathrm{BP}$, these people survived a higher sea level of some $40-50 \mathrm{~cm}$ at around 1000-800 BP.

In this paper, we will concentrate on the present-tofuture perspectives.

\section{New records from the Maldives}

In 1999, the INQUA Commission on Sea Level Changes and Coastal Evolution initiated a special research project in order to decode the history of the Maldives, record the past sea level changes and understand the present-to-future prospect of the islands (INQUA, 2000; Tooley, 2000). In our study of the coastal dynamics and the geomorphology of the shores, we were unable to detect any traces of a recent sea level rise. On the contrary, we found quite clear morphological indications of a recent fall in sea level.

Our information come from numerous islands in the Baa-Raa-Guidhoo Atolls, from Viligili island in the North Male Atoll, from Lhosfushi-GaraidhooKodoomaafushi islands in the South Male Atoll, and from Hithadhoo island in the Addo Atoll (Fig. 2).

Many islands are affected by erosion. Erosion may be caused by sea level rise, sea level lowering, change in wind direction and change in wind intensity. Hence, it is not a measure of sea level rise (as often claimed). The level of re-deposition of the sand and shingle set in motion by erosion is a much better indication of actual sea level changes; moving in over former land if sea level is rising, and adding lower levels seawards if sea is falling.

Erosion may, of course, also be caused by human interference with the coastal dynamics and sediment supply. In the Maldives, there are many examples of severe erosion due to the construction of causeways between islands, dredging, harbour works and sea defences. In most cases, however, those effects are easily understood in terms of actual human coastal activity.

Our observational field data shedding new light on the present to sub-recent sea level changes are expressed in the four graphs (A-D) in Fig. 3.

\subsection{General island morphology}

Fig. 3A illustrates the general morphological situation of all islands studied. It was first observed in the Guidhoo-Baa-Raa Atolls. The islands have a very clear stepwise coastal evolution; (1) a present shore with high-tide level (HTL) and a higher storm level, (2) a sub-recent level that is overgrown by vegetation or in the process of becoming overgrown, and (3) an old island surface with a strong soil profile. This is the general situation from island to island. The section in Fig. 3A is an actual levelled profile from the island of Hulhudhoo in the Baa Atoll. The mean sea level 


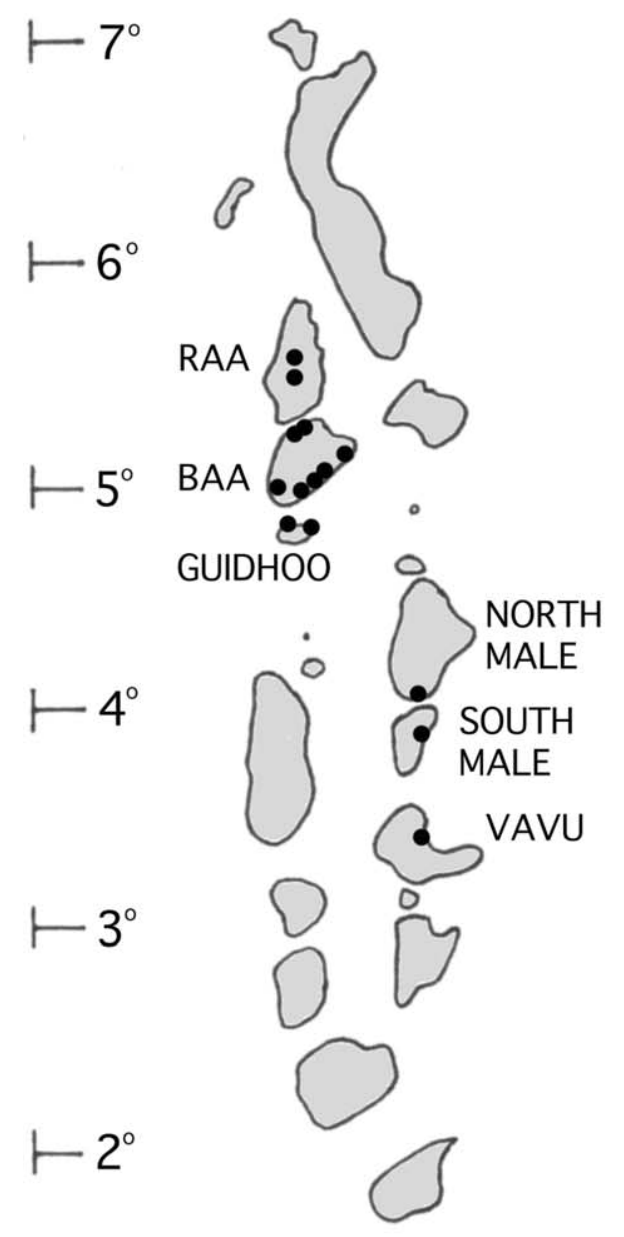

$\mapsto 1^{\circ} \mathrm{N}$

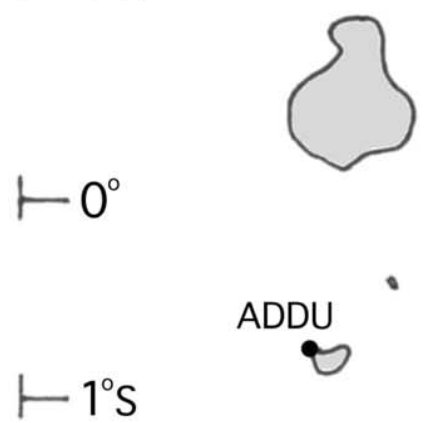

Fig. 2. The Maldives in the central Indian Ocean consists of some 1200 individual islands grouped into about 20 larger atolls. Dots indicate islands studied with respect to present to sub-recent sea level changes. seems closely to approximate the surface of a beach rock cut into a flat surface (a rock cut platform). The HTL is at $+0.45 \mathrm{~m}$, the storm level at $+0.9-0.8 \mathrm{~m}$, the sub-recent level is at $+1.2 \mathrm{~m}$, and the old island surface at $+1.45 \mathrm{~m}$. This seems to indicate that the island surface was built up at a $60 \mathrm{~cm}$ higher sea level and that the sub-recent level was formed at a $30 \mathrm{~cm}$ higher sea level.

A higher sea level of about $+60 \mathrm{~cm}$ in Late Holocene times is recorded in sandy environment (e.g. Hulhudhoo in the Baa Atoll) as well as in beach-rock environment (e.g. Fulhudhoo in the Guidhoo Atoll).

The sub-recent level seems, in general, to have been at about $+30 \mathrm{~cm}$ (in sandy section of the Hulhodhoo as well as in the beach-rock coast of Fulhudhoo).

The most important and interesting fact is the sea level fall of about $20-30 \mathrm{~cm}$ between the sub-recent level and the present level. The morphology is clear, but it does not provide any exact dating. From the shape and freshness, one would assume that the sea level fall took place in the last 50 years, or so.

\subsection{Sailing routes in the Vavu Atoll}

Fig. 3B illustrates the batymetric situation of the Thinadhoo-Felidhoo area on the eastern side of the Vavu Atoll. Here, local people report that the dhonis (local fishing boats) could pass straight across the Maduvvaree Falhu thila (with on old reef surface no longer growing) in the 1970s and early 1980s, whilst they in the last 15 years have had to make a detour around the thila, because it is now too shallow. The thila has not grown, so it must be the sea that has fallen.

This fits perfectly well with the island morphology as discussed above. In this case, however, the sea level fall is dated to the 1970 s to early 1980 s.

\subsection{The "reef woman" at Lhosfushi}

In 1996, a skeleton was found "in the reef" close to the islands of Lhosfushi-Garaidhoo which became known as "the reef woman" from Lhosfushi (Rasheed, 1996). We recently undertook a careful investigation of the site with respect of stratigraphy, morphology and depositional environment (Fig. 3C). The skeleton lies in an indurated beach sand. It is 

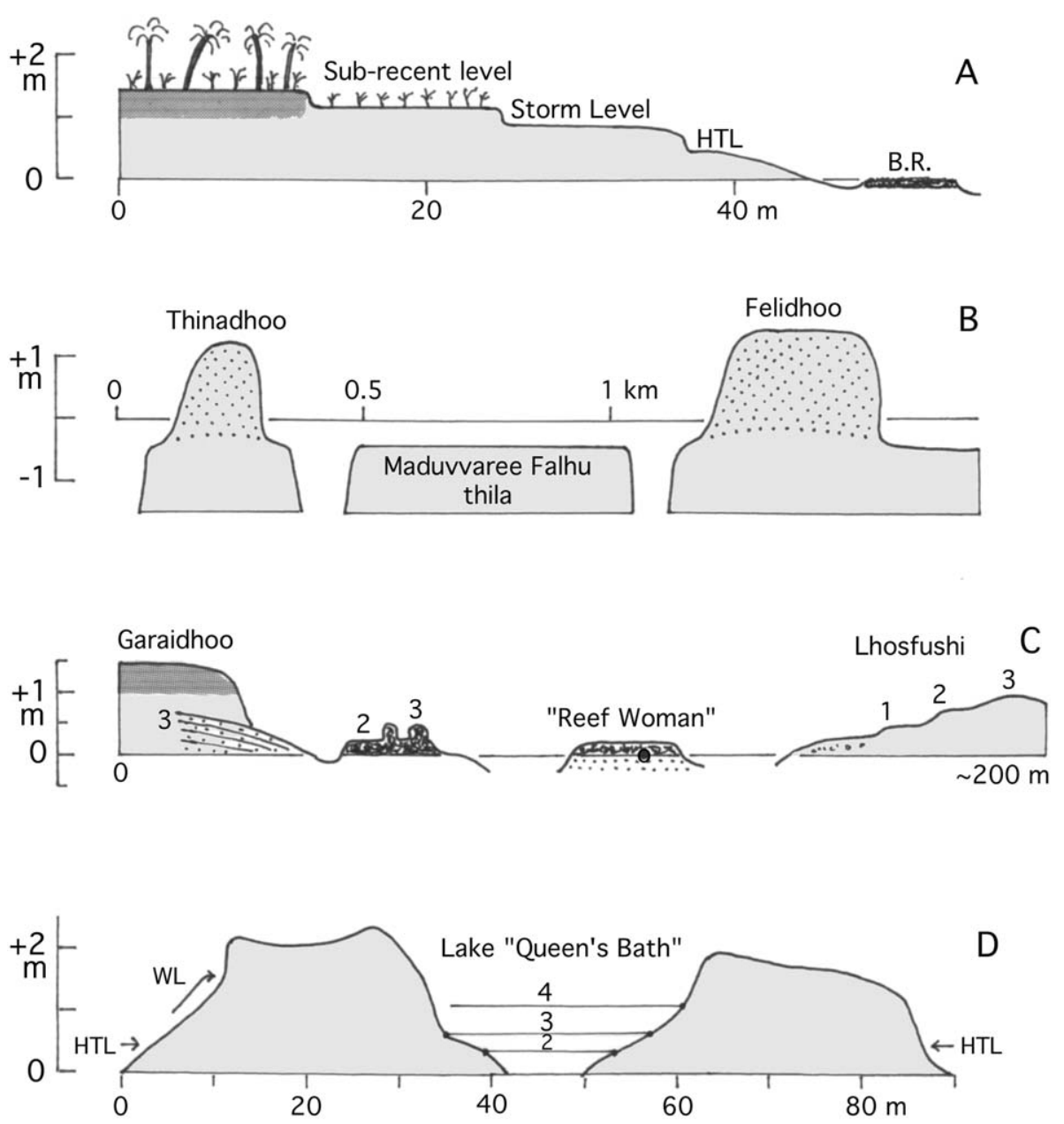

Fig. 3. Coastal sections illustrating Late Holocene and sub-recent to present sea level changes in the Maldives. (A) General island morphology as recorded in the Guidhoo-Baa-Raa Atolls including a stepwise evolution; an old vegetated island surface with a deep soil profile, a subrecent level in the process of becoming overgrown and a present coastal morphology including a storm level, a high-tide level (HTL) and a beach-rock (B.R.) eroded into a flat rock-cut platform at mean sea level (the section refers to an actual profile levelled over the shore of Hulhudhoo in Baa Atoll). (B) Bathymetry and sailing route in the Vavu Atoll where the dhonis could pass from one island to the other straight across the Maduvvaree Falhu thila in the 1970s and early 1980s, but later had to make a detour around the thila because the water had become too shallow. (C) The morpho-stratigraphic situation around the site of "the reef woman" in South Male Atoll; the skeleton (dated at about $1200 \mathrm{BP}$ ) was deposited in a littoral sand, sea level rose by about $40-70 \mathrm{~cm}$ (3), fell back at about the present level, rose again at about $+20 \mathrm{~cm}$ in sub-recent time (2), and finally fell to its present level. (D) Cross-section of the eastern peninsula of Hithadhoo island in the Addu Atoll; two complex beach ridge systems have ponded an elongated lake known as the "Queen's Bath" (HTL=high-tide level, $\mathrm{WL}=$ present washing limit). The lake level fluctuates with the tides and exhibits four shore level; the low water level (1), the high-tide level (2), a sub-recent level (3) and an older Late Holocene level (4).

covered by a coral rubble that is cemented into a beach-rock. At the shore of Garaidhoo, the beach-rock grades into an on-shore sand, now cemented. The surface of the on-shore sand lies about $70 \mathrm{~cm}$ above the present on-shore sand, indicating a higher sea level at that time. Remnants of the beach-rock reach some $40-50 \mathrm{~cm}$ above present mean sea level. The main part of the beach-rock is cut into a rock-cut platform with its surface at about $+20 \mathrm{~cm}$. Along the shore of Lhusfushi, there are three steps and beach ridges; the 
present one, a sub-recent level some $20 \mathrm{~cm}$ higher and an older Late Holocene level an additional $20-30 \mathrm{~cm}$ higher up. The skeleton has been radiocarbon dated at $1225+55 \mathrm{BP}$ (because of a ${ }^{13} \mathrm{C}$ content of - 14.4.\%o, a "sea correction" of some 400 years should be subtracted implying an age of around 800 $\mathrm{BP}$ or $\mathrm{AD} 1150$, i.e. just when the islands became Muslims).

Our interpretation is as follows. The skeleton came in position on a shore at about the same elevation as today. Sea level rose by $40-70 \mathrm{~cm}$, the beach-rock was formed and the island sand was deposited (now having a well-developed soil). Subsequently, sea level fell to a position at about the present mean sea level. This was followed by a sub-recent sea level rise about $20 \mathrm{~cm}$ higher than today's level. A very recent sea level fall brought sea level to its present position. The timing of this sea level fall is not known, but the freshness of the morphological structures suggests an age in the order of 50 years, or so.

\subsection{The morphology of the "Queen's Bath" Lake on Hithadhoo}

The "Queen's Bath" is and elongated lake between two beach ridge systems on the northeastern point of Hithadhoo in the Addo Atoll (Fig. 3D). Water levels in the lake record the tidal cycle. The high-tide level in the lake is at $+35 \mathrm{~cm}$. There is a distinct sub-recent level at $+65 \mathrm{~cm}$ and older level at $+110 \mathrm{~cm}$. This seems to indicate that there was a Late Holocene level at about $+75 \mathrm{~cm}$ and a sub-recent level at $+30 \mathrm{~cm}$ (when adjusted to HTL). This stepwise general evolution fits well with the coastal morphology of the northern islands (Fig. 3A).

The same system was also recorded in other lakes and ponds and lagoonal areas on Hithadhoo.

In large parts of the open coast lines of the Addo Atoll, these small changes can no longer be observed, because the coastal evolution is here dominated by on-going sedimentary reorganisation due to extensive construction works and a recent increase of the NE-monsoon.

\subsection{Summary of recorded sea level changes}

Our data presented here cover the last 1200 years. They were used to construct the later part of the new sea level curve from the Maldives (Fig. 1). At about $1200 \mathrm{BP}$, sea level was at or close to +0 . This level was followed by a sea level rise of about $50-60 \mathrm{~cm}$ (40 to 75 in Fig. 3A-D) at about 1000-800 BP. Subsequently, sea level seems to have fallen back to the present level. In sub-recent time some 100 to 30 years ago, sea level was $20-30 \mathrm{~cm}$ higher than it is today $(20-30 \mathrm{~cm}$ in Fig. $3 \mathrm{~A}, 20 \mathrm{~cm}$ in Fig. $3 \mathrm{C}$, and $30 \mathrm{~cm}$ in Fig. 3D). In the 1970s to early 1980s, sea level experienced a general fall of the order of $20-30 \mathrm{~cm}$.

\section{Discussion}

The sea level fall in the 1970s to early 1980s is of special interest. It opens quite new perspectives and hence calls for further discussion.

In the IPCC scenarios, the Maldives were condemned to disappear in the sea in the near future (e.g. Hoffman et al., 1983; IPCC, 2001). Our documentation of actual field evidence contradicts this hypothesis.

Tide gauge data have been cited in support of an on-going rise of mean sea level (Singh et al., 2001). Tide gauge records, however, do not provide simple and straight-forward measures of regional eustatic sea level. They are often (not to say usually) dominated by the effects of local compaction and local loading subsidence. With this perspective, our multiple morphological and sedimentological records appear more reliable and conclusive. Besides, satellite altimetry does not record any significant rise in global sea level in the last decades (Mörner, 2003a, Fig. 2). In order fully to investigate the situation, however, available tide gauge records, now extending from 1990 to 2002, were re-examined. This reveals a total absence of any rising secular trend (Mörner, 2003b).

A recent sea level fall of the order of 20 to $30 \mathrm{~cm}$ in the last 30 years is most surprising. Both rates $(>10$ $\mathrm{mm} /$ year) and amplitudes (20 to $30 \mathrm{~cm}$ ) are much higher than expected. This sea level fall must represent a regional eustatic change confined to the central Indian Ocean.

In the central Indian Ocean, eustatic sea level lies well below the geoid surface because of an exceptionally high rate of evaporation (Mörner, 2000). Therefore, if this evaporation increases further, sea 
level will fall regionally (i.e. just as recorded in this paper).

We, therefore, propose that the sea level regression recorded in our observational data is the effect of increased evaporation. This fits with an increase of the NE-monsoon in the last decades as recorded in so many islands; not least in Addu Atoll.

It seems significant that Pfeiffer et al. (2001) recorded a marked environmental change at about 1970 in the stable isotopes of corals from the Chagos Islands (south of the Maldives). They interpreted this in terms of decreased precipitation linked to the monsoonal circulation.

\section{Conclusions}

In the region of the Maldives, a general fall of sea level occurred some 30 years ago. The origin of this sea level fall is likely to be an increased evaporation over the central Indian Ocean linked to an intensification of the NE-monsoon.

Furthermore, there seems no longer to be any reasons to condemn the Maldives to become flooded in the near future.

Besides, at about 1000-800 BP, the people of the Maldives survived a higher sea level by about $50-60 \mathrm{~cm}$.

\section{Acknowledgements}

We thank all other members of the Maldives Project for their participation, viz. partly our own group within INQUA (N.-A. Mörner, M.J. Tooley, J. Laborel, F. Laborel, S. Dawson, J. Collina, W. Allison, C. Rufin, D. Dominey-Howes, B. Lembke, A. Dupuch, M. Banfield, and, from the Maldives, M. Zhair, M. Manik, H. Maniku, Sea Explorers, Whale Submarine) and partly the representatives of the Ministry of Home Affairs, Housing and Environment in Male (M. Khaleel and M. Ali). We also acknowledge constructive collaboration with A. Ibrahim and N. Mohamed at the National Centre for Linguistic and
Historical Research, where the remains of the "Reef Woman" will be deposited.

After this paper was completed, we obtained a series of radiocarbon dates of sea level changes recorded in two swamps on the Guidhoo Atoll which fully confirm our findings and add further fixed data points on the sea level curve of the last 1000 years.

\section{References}

Agassiz, A., 1903. The coral reefs of the Maldives. Mem. Mus. Comp. Zoology Harv. Coll. 29, 1-168.

Anderson, R.C., 1998. Submarine topography of Maldivian atolls suggests a sea level of 130 metres below present at the last glaciation maximum. Coral Reefs 17, 339-341.

Barbu, E.M. (Ed.), 1988. Proc. ODP, Initial Reports, p. 115.

Davis, P.S., Stoddart, D.R., Sigeo, D.C., 1971. Reef forms of Addu Atoll, Maldive Islands. Symp. Zool. Soc. Lond. 28, 217-259.

Gardiner, J.S., 1902. The formation of the Maldives. Geogr. J. 19, $277-301$.

Hoffman, J.S., Keyes, D., Titus, J.G., 1983. Projecting Future Sea Level Rise. U.S. Environmental Protection Agency, Washington, DC Gov. Print. Office. 266 pp.

INQUA, 2000. Homepage of the Commission on Sea Level Changes and Coastal Evolution, www.pog.su.se/sea. Sea level changes, News and Views, The Maldives Project.

IPCC, 2001. Climate Change 2001. Cambridge Univ. Press.

Mörner, N.-A., 2000. Sea level changes in the Indian Ocean. Integrated Coastal Zone Management, Launch Ed. IPC Publ., pp. $17-20$.

Mörner, N.-A., 2003a. Estimating future sea level changes from past records. Glob. Planet. Change 40, 49-54 (this issue).

Mörner, N.-A., 2003b. No flooding of the Maldives. Submitted.

Pfeiffer, M., Dullo, C., Eisenhauer, A., 2001. Indian Ocean reef corals: evidence for secular changes in monsoon circulation? In: Ruth, S., Rüggenberg, A. (Eds.), 2001 Margins Meeting Schrift. Deutschen Geol. Gesellschaft, vol. 14, pp. 151-152.

Prudy, E.G., 1981. Evolution of the Maldive atolls, Indian Ocean. Proc 4th Int. Corral Reef Symp. 1, 659.

Rasheed, I.K., 1996. Dead woman resting. Haveeru (Male), Dec. 12-13, 1996.

Singh, O.P., Ali Khan, T.M., Aktar, F., Sarker, M.A., 2001. Recent sea level and sea surface temperature change along the Maldives coast. Mar. Geod. 24, 209-218.

Tooley, M., 2000. Sea level? Quat. Perspect. 11 (1), 1.

Woodroffe, C.D., 1992. Morphology and evolution of reef islands in the Maldives. Proc. 7th Int. Coral Reef Symp., Gaum 2, 1217-1226. 